\title{
ERRATUM
}

\section{Erratum to "Biology and the Statistic Demographic of Aphis glycines Matsumura (Hemiptera: Aphididae) on the Soybean with Plant Growth Promoting Rhizobacteria (PGPR) Treatment" [Jurnal Perlindungan Tanaman Indonesia, 24(1), 54-60]}

\author{
Hermanu Triwidodo ${ }^{1) *}$, Anggun Agustini ${ }^{1)}$, \& Listihani $^{2)}$ \\ ${ }^{1)}$ Department of Plant Protection, Faculty of Agriculture, IPB University \\ Jln. Kamper, Kampus IPB Dramaga, Bogor, West Java 16680 Indonesia \\ ${ }^{2}$ Faculty of Agriculture and Business, University of Mahasaraswati Denpasar \\ Jin. Kamboja No.11 A, Dangin Puri Kangin, Denpasar Utara, Bali 80233 Indonesia \\ *Corresponding author. E-mail: hermanutr@apps.ipb.ac.id
}

Erratum: Hermanu Triwidodo, Anggun Agustini, \& Listihani. (2020). Jurnal Perlindungan Tanaman Indonesia, 24(1): 54-60. (doi: 10.22146/jpti.49846). In Author's affiliation, typed as:

$$
\begin{aligned}
& \text { Hermanu Triwidodo' }{ }^{1) *} \text {, Anggun Agustini }{ }^{1)}, \text { \& } \text { Listihani }^{1)} \\
& { }^{1)} \text { Department of Plant Protection, Faculty of Agriculture, IPB University } \\
& \text { Jin. Kamper, Kampus IPB Dramaga, Bogor, West Java } 16680 \text { Indonesia }
\end{aligned}
$$

Therefore, the Author's affiliation was corrected to:

$$
\begin{aligned}
& \text { Hermanu Triwidodo')*, Anggun Agustini'1), \& Listihani }{ }^{2)} \\
& { }^{1)} \text { Department of Plant Protection, Faculty of Agriculture, IPB University } \\
& \text { Jln. Kamper, Kampus IPB Dramaga, Bogor, West Java } 16680 \text { Indonesia } \\
& { }^{2)} \text { Faculty of Agriculture and Business, University of Mahasaraswati Denpasar } \\
& \text { Jin. Kamboja No.11 A, Dangin Puri Kangin, Denpasar Utara, Bali } 80233 \text { Indonesia }
\end{aligned}
$$

The editorial staff apologizes for the inconvenience. The online version of the corrected manuscript has been published in the open journal system of the Jurnal Perlindungan Tanaman Indonesia.

How to Cite: Triwidodo, H., Agustini, A., \& Listihani. (2021). Biology and the Statistic Demographic of Aphis glycines Matsumura (Hemiptera: Aphididae) on the Soybean with Plant Growth Promoting Rhizobacteria (PGPR) Treatment. Jurnal Perlindungan Tanaman Indonesia, 24(1), 54-60; erratum, 25(1), 98. https://doi. org/10.22146/jpti.68694 